\title{
Bird Use of Northern Alaska Oilfield Rehabilitation Sites
}

\author{
Rebecca Bentzen, ${ }^{1,2}$ Joe Liebezeit, ${ }^{3}$ Martin Robards, ${ }^{1}$ Bill Streever, ${ }^{4}$ Samantha Strindberg ${ }^{5}$ and Steve Zack ${ }^{1}$
}

(Received 19 July 2017; accepted in revised form 30 July 2018)

\begin{abstract}
Breeding bird response to habitat rehabilitation after anthropogenic disturbance has received little attention in the Arctic. The North Slope of Alaska is an important breeding ground for many populations of migratory birds and has also supported major oilfields since the late 1960s. The most obvious impacts of industrial development to nesting birds are direct habitat loss and fragmentation resulting from the construction of infrastructure, along with increased mechanical noise, vehicle traffic, and other forms of anthropogenic disturbance. In response to state and federal requirements, efforts have been made to rehabilitate abandoned portions of the oilfields. We compared bird use at rehabilitation sites and at nearby paired reference sites. Densities of shorebirds and passerines varied between rehabilitation sites and reference sites, but waterfowl densities did not. Specifically, passerine and shorebird densities were higher at reference sites in the early or mid-season and lower at reference sites in the late season. Additionally, birds on rehabilitation sites were primarily observed foraging and resting, while behavior observed on paired reference sites was more diverse and included courtship displays, nesting, and aggression. Further, rehabilitation sites supported significantly fewer nests and fewer species than recorded at reference sites. Our findings suggest that sites 3 to 10 years post rehabilitation do not provide bird habitat comparable to nearby reference sites and, by extension, do not provide shorebird and passerine habitat comparable to that found prior to development. However, rehabilitation sites appear to provide adequate habitat for waterfowl and are important to shorebirds and passerines as foraging areas. Continued monitoring will be needed to establish the long-term suitability of rehabilitation sites, compared to reference sites, as breeding habitat for birds.
\end{abstract}

Key words: Arctic; breeding birds; nest density; post-development; rehabilitation; tundra

RÉSUMÉ. Dans l'Arctique, la réponse des oiseaux nicheurs à la remise en valeur de l'habitat après des perturbations d'origine anthropique a été peu étudiée. Le North Slope de l'Alaska est un lieu de reproduction important pour de nombreuses populations d'oiseaux migrateurs. Des champs pétroliers d'envergure y ont également été aménagés depuis la fin des années 1960. Les incidences les plus évidentes du développement industriel sur les oiseaux nicheurs sont la fragmentation et la perte directe d'habitat découlant de la construction d'infrastructures ainsi que l'augmentation du bruit mécanique, de la circulation de véhicules et d'autres formes de perturbations anthropiques. En raison des exigences de l'État et de l'administration fédérale, des efforts ont été déployés pour remettre en valeur les zones abandonnées des champs pétroliers. Nous avons comparé l'utilisation par les oiseaux des lieux remis en valeur à des lieux de référence jumelés des environs. Les densités d'oiseaux de rivage et de passereaux variaient dans les lieux remis en valeur et les lieux de référence, mais ce n'était pas le cas des densités de la sauvagine. Plus précisément, les densités de passereaux et d'oiseaux de rivage étaient plus élevées aux lieux de référence en début ou en milieu de saison, et moins élevées aux lieux de référence en fin de saison. De plus, les oiseaux de lieux remis en valeur ont surtout été vus en train de se nourrir ou de se reposer, tandis qu'aux lieux de référence, leurs comportements étaient plus variés et comprenaient des comportements de parade nuptiale, de nidification et d'agression. Par ailleurs, les lieux remis en valeur abritaient un beaucoup moins grand nombre de nids et moins d'espèces que les lieux de référence. Selon nos constatations, de trois à dix ans après les travaux de remise en valeur, ces lieux ne présentent pas, pour les oiseaux, un habitat comparable aux lieux de référence des environs et, par conséquent, ils ne fournissent pas aux passereaux et aux oiseaux de rivage un habitat comparable à celui qui s'y trouvait avant le développement industriel. Toutefois, les lieux remis en valeur semblent présenter un habitat adéquat pour la sauvagine et revêtent de l'importance comme lieux de ravitaillement pour les oiseaux de rivage et les passereaux. Une surveillance continue s'avère nécessaire afin d'établir la convenance à long terme des lieux remis en valeur, comparativement aux lieux de référence, comme habitat de nidification pour les oiseaux.

Mots clés : Arctique; oiseaux nicheurs; densité de nids; après le développement; remise en valeur; toundra

Traduit pour la revue Arctic par Nicole Giguère.

\footnotetext{
${ }^{1}$ Wildlife Conservation Society, Arctic Beringia Program, 3550 Airport Way, Suite 5, Fairbanks, Alaska 99709, USA

${ }^{2}$ Corresponding author: rbentzen@wcs.org

${ }^{3}$ Audubon Society of Portland, 5151 NW Cornell Rd., Portland, Oregon 97210, USA

${ }^{4}$ LAMA Ecological, 3824 Cedar Springs Road, \#801-2771, Dallas, Texas 75219, USA

${ }^{5}$ Wildlife Conservation Society, Global Conservation Program, 2300 Southern Boulevard, Bronx, New York, New York 10460, USA

(C) The Arctic Institute of North America
} 


\section{INTRODUCTION}

Assessing the success of habitat rehabilitation efforts for sites that have been disturbed as a result of industrial activities is of great interest, both scientifically (e.g., to applied and rehabilitation ecologists) and as a contribution to the regulatory process (under the guidance of Dismantlement, Removal, and Remediation policies, Section 404 of the Clean Water Act, and others). Of particular interest is the ability of rehabilitation sites to support wildlife by providing ecological functions in a manner similar to that of relatively undisturbed habitat. Also, determining over what timelines a rehabilitation site matures is of great importance to evaluating wildlife use (Ormerod, 2003; Ruiz-Jaen and Aide, 2005).

The coastal plain of northern Alaska is a vitally important breeding ground for populations of over 40 species of migratory birds (Johnson and Herter, 1989; Johnson et al., 2007; Bart et al., 2013). Millions of these birds nest in this region during the short and productive Arctic summer. In particular, shorebird diversity and abundance can be particularly high in the Arctic compared to many other parts of the world (Andres et al., 2012; Bart et al., 2013). There are also many oilfields on the coastal plain, including two of the top 10 largest oilfields in the United States, one located at Prudhoe Bay and the other along the nearby Kuparuk River (U.S. Energy Information Administration, 2015). Although the various oilfields have operational boundaries, the end effect is one of more or less continuous development stretching across about $150 \mathrm{~km}$ of the coastal plain.

Despite efforts to minimize disturbance, oil development in this region impacts wildlife, including nesting birds, in a number of ways (National Research Council, 2003). The most direct impact is the placement of oil infrastructure on the landscape, resulting in habitat loss and fragmentation. Arctic conditions necessitate building structures on a thick gravel layer to protect the permafrost from thawing, which maintains a stable working surface to support operations. Despite technological improvements and regulatory constraints that have helped to minimize the development footprint, 4107 hectares of land had been directly impacted by gravel placement (e.g., tundra that is beneath roads, pads, and airstrips) as of 2011 (Raynolds et al., 2014). Future oil development is likely to expand this footprint.

The need to restore wildlife habitat on the Arctic coastal plain has been recognized since the inception of development and was one of the key concerns highlighted in the National Research Council's (2003) evaluation of cumulative effects of oil development in the Arctic. BP Exploration (Alaska), Inc. and other oilfield operators, supported by various contractors, began efforts to rehabilitate abandoned exploration drilling pads, landing strips, roads, oil spill sites, and other ground disturbance associated with development in the early 1970s (Jorgenson and Joyce, 1994; Streever et al., 2003; Kidd et al., 2004).

While Arctic rehabilitation efforts associated with industrial development have received relatively little attention with respect to birds, this has been a rich topic in more temperate latitudes in the context of grassland reclamation at abandoned mining sites (DeVault et al., 2002; Galligan et al., 2006; Duncan, 2011). The importance of the specific vegetation used to rehabilitate mines has been shown to affect which birds use the area (e.g., Scott and Lima, 2004). Likewise, changes in vegetation as rehabilitation sites mature are known to affect how birds use these sites (e.g., Šálek, 2012). In addition, bird use varied depending on whether sites were actively rehabilitated or left to revegetate naturally (Š́lek, 2012). The sites investigated in this study were primarily revegetated with species that are indigenous to the Arctic and that can either be seeded or that colonize naturally following disturbance.

Cardoso da Silva and Vickery (2002) argued that birds are one of the best indicator-animal groups for evaluating the success of large-scale ecosystem rehabilitation because of their high dispersal ability. Our goal was to assess Arcticbreeding bird use of rehabilitation efforts on the coastal plain of Alaska. Specifically, we compared bird behavior, species composition, and densities of birds and nests on rehabilitation sites and nearby relatively undisturbed reference sites. Despite intensive rehabilitation involving gravel removal, reintroduction of native tundra vegetation, and reshaping topography at many sites across the study area, as far as we are aware, this is the first primary literature publication to systematically evaluate bird use of rehabilitation sites on Alaska's Arctic coastal plain.

\section{METHODS}

\section{Study Site}

Fieldwork was conducted on Alaska's Arctic coastal plain in the Prudhoe Bay oilfield in June and July 2012-14. The study site is in an area developed for petroleum production with an associated road network and industrial activities. The site is characterized by a vast number of lakes, ponds, and other water bodies that overlay extensive permafrost. Primary wetland community types found at the sites include wet sedge meadows, moist sedge-dwarf shrub (e.g., willow) meadows, tussock tundra, and emergent sedge and pendant grass on the margins of lakes and ponds (Anderson et al., 1999).

\section{Field Methods}

We selected 10 rehabilitation sites (online Appendix 1) and 10 paired relatively undisturbed reference sites located on nearby undeveloped land in the Prudhoe Bay oilfield (Fig. 1). Paired undeveloped sites were delineated on four existing 10 ha study plots that were originally established in 2003 as part of a long-term tundra bird nest-monitoring project (Bentzen, 2016). Only those portions of these plots that matched the area of paired rehabilitation sites were surveyed to avoid sampling area bias. Rehabilitation 


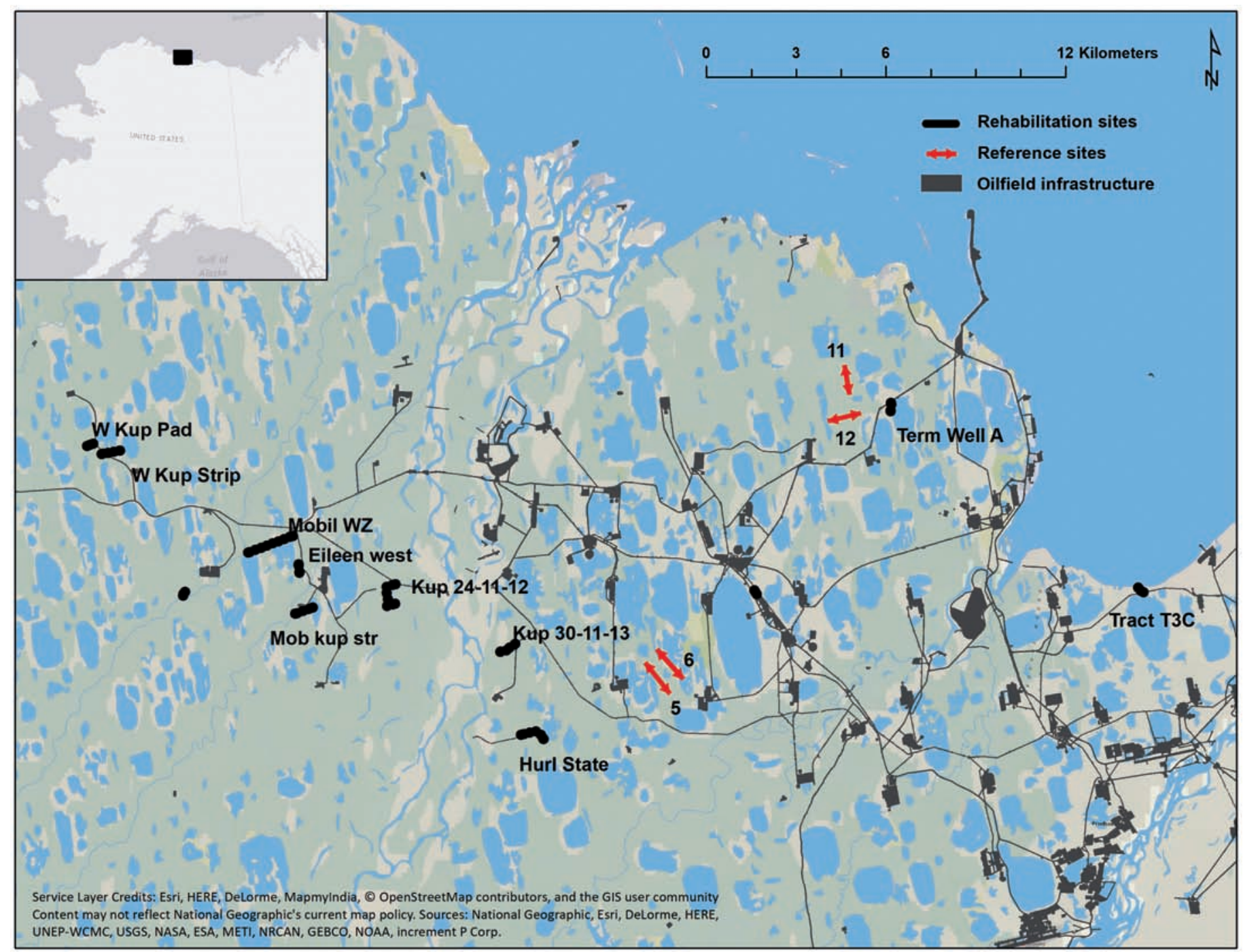

FIG. 1. Study area at Prudhoe Bay Oilfield, Alaska, 2012-14. The 10 rehabilitation sites are identified by name (for details, see online Table S1). The 10 paired reference sites were delineated on four existing 10 ha study plots, shown on the map with numbers 5, 6, 11, and 12 .

sites Hurl State (transect length $1107 \mathrm{~m}$ ) and W Kup Strip $(629 \mathrm{~m})$ were paired with portions of tundra site 5 (600 m and $200 \mathrm{~m}$, respectively), Kup 24-11-12 (1280 m), Tract T3C $(251 \mathrm{~m})$, and Eileen West $(302 \mathrm{~m})$ were paired with portions of tundra site $6(550 \mathrm{~m}, 250 \mathrm{~m}$, and $250 \mathrm{~m}$, respectively), Term Well A (293 m) and Mob WZ (1591 m) were paired with portions of tundra site $11(300 \mathrm{~m}$ and 700 m, respectively), and W Kup Pad (217 m), Kup 30-11-13 (586 m), and Mob Kup State Strip (571 m) were paired with portions of tundra site $12(150 \mathrm{~m}, 350 \mathrm{~m}$, and $200 \mathrm{~m}$, respectively; Fig. 1). Paired tundra sites were selected randomly out of the set of long-term plots with the exclusion of plots that were too logistically challenging.

While our study seeks to compare rehabilitation sites to relatively undisturbed tundra reference sites, we emphasize that our assessment took place during the early stages of a long-term rehabilitation period. The rehabilitation sites investigated in this study were initially seeded and fertilized 3-10 years prior to our work (online Appendix 1). Rehabilitation at the sites evaluated in this study typically involved removing the majority of gravel from pads, roads, and airstrips, excavating and backfilling reserve pits and sewage holding ponds, application of fertilizer and seeding of native grass or legumes or both, and occasionally planting native willow cuttings (Streever et al., 2003; Kidd et al., 2004, 2006; see online Appendix 1).

We conducted three line transect counts (early-, mid-, and late-season) on rehabilitation sites and reference sites in 2012, 2013, and 2014. The first count was in early June (4-13 June) when birds were preparing to nest, setting up territories, and displaying. The second count was in mid-June (13 June -5 July) when birds were less visible due to nesting. The last count was in July (27 June -8 July) when birds were hatching and fledging. Although there was overlap between season dates between years there was no overlap within years. Radial distances and angles were recorded from the line transects to permit calculation of the perpendicular distance used during line transect distance sampling analysis. Cluster size (i.e., number of birds in a group) was recorded for each observation. In all cases, observations of birds that were 
flying over the sampling site or detected outside the sampling site were excluded from analyses.

We conducted two single-person nest searches at all rehabilitation and reference sites using behavioral techniques described in Liebezeit et al. (2009) to determine nest density. Single-person searches were conducted by one observer who searched for nests following a systematic route within each approximate $50 \mathrm{~m} \times 50 \mathrm{~m}$ grid at each site. The first nest search took place during the midseason period, and the second in the late-season period. Further, we conducted two area search surveys (Dieni and Jones, 2002) at each site in each season, and recorded all observations of birds using the sites. Bird behavior for each observation was recorded as nesting, preening, displaying, brood rearing, aggressive interaction, foraging or loafing.

\section{Statistical Methods}

To estimate bird densities on the rehabilitation and reference sites we used distance sampling techniques that have been successfully used to obtain density and abundance estimates for a large number of free-roaming animal species (Buckland et al., 2001). During a distance sampling analysis a detection function is fitted to the perpendicular distances calculated from the radial distances and angles recorded for each bird group observed in the area sampled along the transect lines. The detection probability estimated by means of this function is used to correct for the proportion of bird groups in the sampled area that were not counted. Distance software was used to analyze the data (Thomas et al., 2010). Encounter rate and cluster size were stratified by treatment (rehabilitation vs. reference site), survey season $(2012,2013,2014)$, bird guild (passerine, shorebird, waterfowl), and sampling occasion (early, middle or late in the season). Variance of encounter rate was estimated empirically using the replicate transect lines as samples. To investigate potential size bias in estimation of cluster size, we considered the expected cluster size estimated when fitting a regression line to cluster size versus distance from the line at a $15 \%$ significance level. Maximum likelihood methods were used to estimate the variance of the effective strip width (ESW), where ESW is the distance from the transect line where the number of bird groups missed within that distance is equal to the number of groups seen beyond that distance. Exploratory analyses were first conducted to examine options for truncation and grouping intervals to improve the fit of the model used for the detection function. Given the small sample sizes at some levels of stratification, some detection functions were fitted using the Multiple Covariate Distance Sampling option with treatment as a factor covariate (Marques and Buckland, 2003), given the assumption of detection varying by treatment. In a few instances, we fit the detection function using the Conventional Distance Sampling option. Goodness-of-fit tests were used to identify violations of assumptions. Akaike's Information Criterion for small sample sizes $\left(\mathrm{AIC}_{c}\right)$ was used in model selection, with particular attention paid to model fit at distances near zero since the fit of the shoulder near zero is most important for robust estimation (Buckland et al., 2001). Estimates of density were obtained by treatment/year combination for the three guilds and for each treatment/sample occasion combination for each guild. We also obtained density estimates using the same detection functions as described by guild above but using a different stratification for encounter rate and cluster size corresponding to the three sampling occasions (early, mid, and late) per survey season for each guild. We compared bird density estimates using a two-sided z-test and considered results significant at $\alpha<0.05$.

We compared nest density between rehabilitation and reference sites with a paired two-sample t-test. Bird behaviors were grouped into foraging, resting (loafing and preening), or breeding (nesting, displaying, brood rearing, and aggressive interaction) and differences between rehabilitation and reference sites were evaluated with a chi-square test as were differences between years on rehabilitation sites. Results were considered significant at $\alpha<0.05$. Values are reported as means $\pm \mathrm{SE}$.

\section{RESULTS}

The most commonly recorded passerine at both rehabilitation and reference sites was the Lapland Longspur (Calcarius lapponicus; $91 \%$ and $100 \%$ of all passerines recorded at rehabilitation and reference sites respectively; Fig. 2). The most common shorebirds at rehabilitation sites were Semipalmated Sandpipers (Calidris pusilla; $54 \%$ of shorebirds recorded), Red-necked Phalaropes (Phalaropus lobatus; 22\%), Semipalmated Plovers (Charadrius semipalmatus; 11\%), and Pectoral Sandpipers (C. melanotos; 9\%). Similarly, the most common shorebirds at reference sites were Semipalmated Sandpipers (29\%), Red-necked Phalaropes (16\%), Pectoral Sandpipers (33\%), as well as Long-billed Dowitchers (Limnodromus scolopaceus; $8 \%$; Fig. 2). The most common waterfowl recorded at rehabilitation sites were Cackling Goose (Branta hutchinsii; 40\%) and Greater White-fronted Goose (Anser albifrons; 40\%). The most common waterfowl recorded at reference sites was the Greater White-fronted Goose (80\%; Fig. 2)

Bird behavior varied between rehabilitation and paired reference sites $\left(\chi^{2}=77.6, p<0.05\right)$. Birds on rehabilitation sites were primarily observed foraging and resting, while behavior observed on reference sites was more diverse, including behaviors associated with breeding (Table 1). Bird behavior varied between years on rehabilitation sites $\left(\chi^{2}=30.6, p<0.05\right)$.

\section{Density Estimates}

Shorebird densities were consistently, but not significantly, higher than the other guilds across treatment 


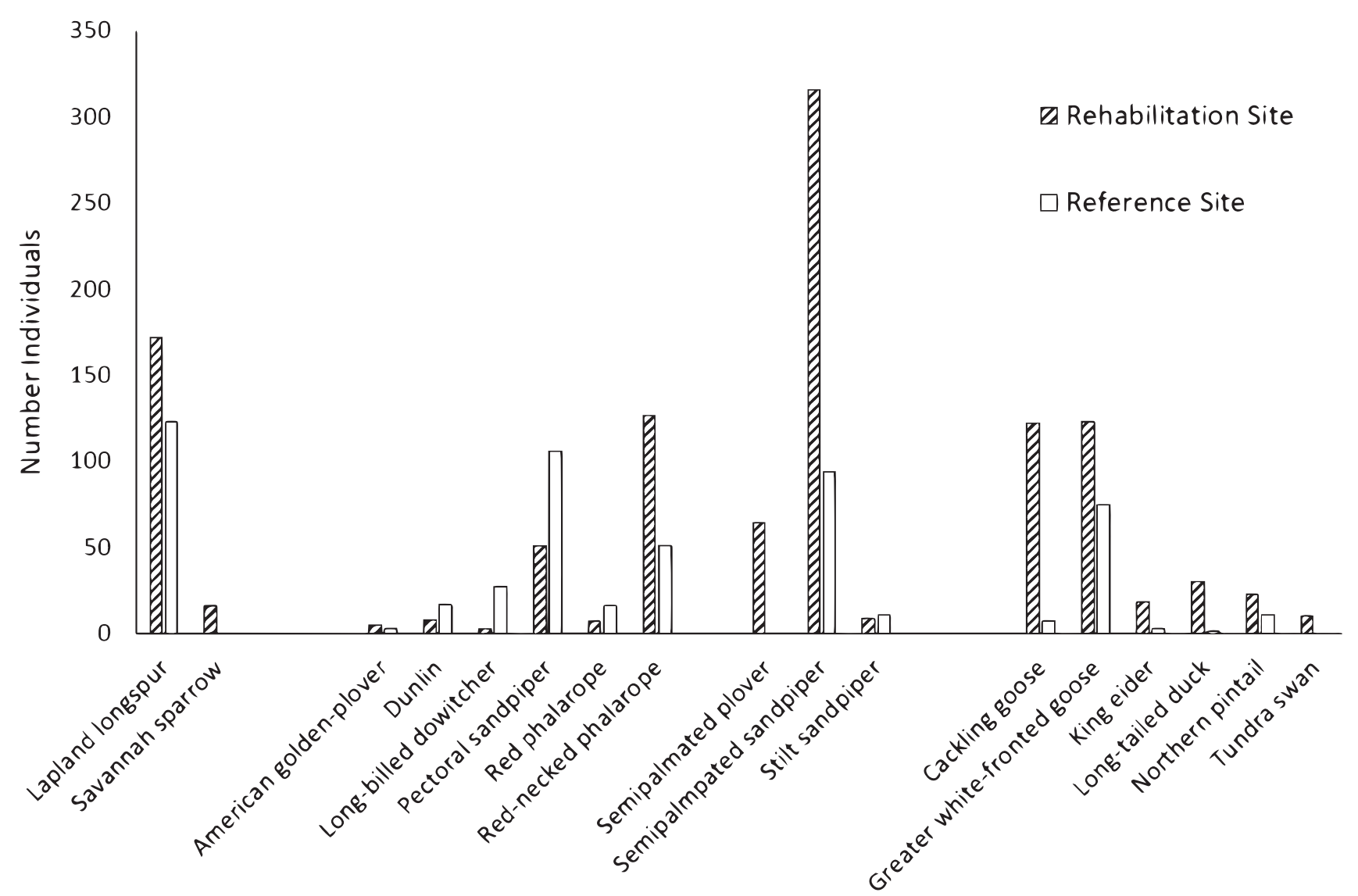

FIG. 2. Number of common birds detected on rehabilitation and paired reference sites across years during line transect counts, Prudhoe Bay Oilfield, Alaska, June-July $2012-14$.

TABLE 1. Total numbers of birds observed on rehabilitation and reference sites during searches by behavioral category summed across years.

\begin{tabular}{lcc}
\hline \hline & Rehabilitation site & Reference site \\
\hline Foraging & 413 & 204 \\
Resting & 599 & 349 \\
Breeding & 101 & 173 \\
\hline \hline
\end{tabular}

and survey years, while passerines and waterfowl were at comparable densities (Fig. 3). For all guilds, a 10\% right truncation of the data gave the best model fit. Line-transect data for all guilds showed signs of responsive movement away from the observers (and away from the transect line), which can negatively bias estimates of density. In addition, line-transect data showed signs of heaping at zero or small distances, which tends to produce positively biased estimates of density. Heaping may be due to difficulty in accurately measuring the small angles during line transect distance sampling or due to a more open line of sight along or close to the transect. Detectability was lower on the rehabilitation sites with detectability declining more rapidly with distance from the line than at reference sites for all guilds.

Passerines: The passerine data pooled across survey years was truncated at $40.0 \mathrm{~m}$ and placed in seven equalsized intervals. The best fitting model was a half-normal function with no adjustment terms with an overall detection probability of just under $57 \%$ (SE $=2.4 \%$ ) and an effective strip width of $22.9 \mathrm{~m}(\mathrm{SE}=0.95 \mathrm{~m})$. Passerine density did not vary significantly between reference and rehabilitation sites for any of the survey years $(2012, Z=0.62 ; 2013$, $Z=0.23 ; 2014, Z=-0.08 ; p>0.05$ for each survey year; Fig. 3). The encounter rate and density estimates for passerines were highest in 2013 (Fig. 3). Uncertainty in the density estimates was mostly due to estimation uncertainty in the encounter rate $(91.6 \%-95.4 \%$ of the variance), followed by the cluster size $(2.5 \%-5.7 \%)$ and the detection function $(1.6 \%-5.3 \%)$.

Shorebirds: The shorebird data pooled across survey years was truncated at $38.9 \mathrm{~m}$ and placed in six equal-sized intervals. The best fitting model was a half-normal function, no adjustment terms, an overall detection probability of just under $55 \%(\mathrm{SE}=1.5 \%)$, and an effective strip width of $21.3 \mathrm{~m}(\mathrm{SE}=0.57 \mathrm{~m})$. The encounter rate and densities for shorebirds were highest at the rehabilitation sites in 2013; however, densities did not vary significantly between reference and rehabilitation sites $(2012, Z=-0.14 ; 2013$, $Z=-1.57 ; 2014, Z=1.15 ; p>0.05$ for each survey year; Fig. 3). Uncertainty in the density estimates was mostly due to estimation uncertainty in the encounter rate $(69.2 \%-96.9 \%$ of the variance), followed by the cluster size $(1.6 \%-13.2 \%)$ and the detection function $(1.5 \%-4.3 \%)$. 


\section{Shorebirds}
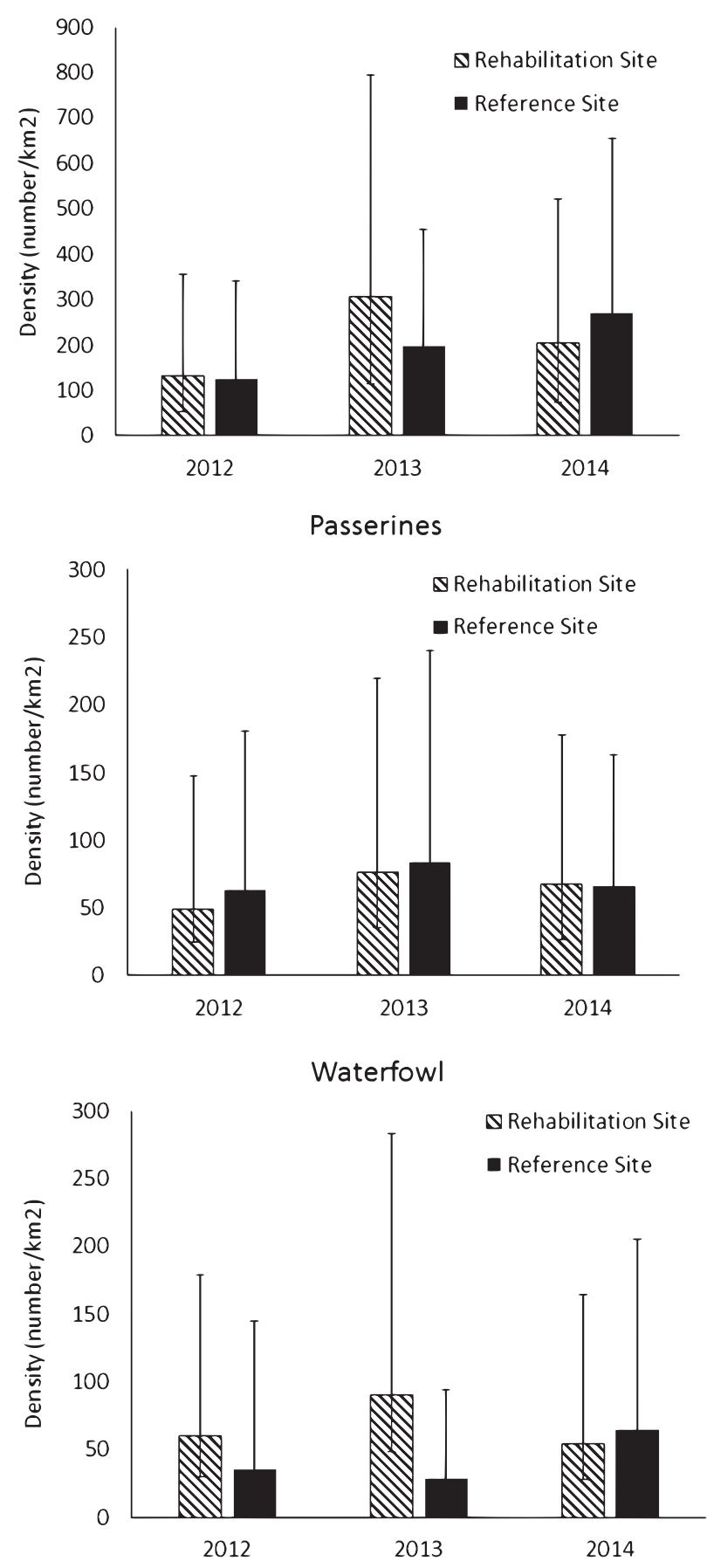

FIG. 3. Density estimates for each guild by treatment (rehabilitation versus reference sites) and survey year for line transects. Shown are estimates of density $(\hat{D})$ in number $/ \mathrm{km}^{2}$ with their $95 \%$ confidence intervals $(95 \% \mathrm{CI})$.

Waterfowl: The waterfowl data pooled across survey years was truncated at $69.2 \mathrm{~m}$ and placed in five equalsized intervals. The best fitting model was a hazard function with no adjustment terms, an overall detection probability of just under $50 \%(\mathrm{SE}=1.1 \%)$, and an effective strip width of $34.5 \mathrm{~m}(\mathrm{SE}=7.8 \mathrm{~m})$. The encounter rate and density estimates for waterfowl were highest at the rehabilitation sites in 2013, and higher on rehabilitation sites than reference sites in the first two years of the study, but were not significantly different between rehabilitation and reference sites $(2012, Z=-0.96 ; 2013, Z=-1.83 ; 2014$, $Z=0.36 ; p>0.05$ (all years); Fig. 3). Uncertainty in the density estimates in all cases was mostly due to estimation uncertainty in the encounter rate $(43.6 \%-77.8 \%$ of the variance), followed by the cluster size $(6 \%-15.4 \%)$ and the detection function $(16.2 \%-41 \%)$.

Seasonal Variation: We found significant seasonal variation in density estimates (birds $/ \mathrm{km}^{2}$ ) between reference and rehabilitation sites for passerines and shorebirds, but not for waterfowl (Fig. 4). Density estimates for passerines and shorebirds tended to be lower at rehabilitation sites than reference sites, but this difference was only significant for passerines in mid-season $(Z=1.97$, $p=0.048)$, and for shorebirds in early-season $(\mathrm{Z}=3.3$, $p<0.0001)$. In contrast, late-season densities of passerines and shorebirds were significantly higher at rehabilitation than reference sites (passerines, $\mathrm{Z}=-2.6$, $p<0.01$; shorebirds, $\mathrm{Z}=-2.64, p<0.01$ ). Significant seasonal variation was not detected in waterfowl density estimates, although waterfowl density was higher on rehabilitation sites in mid- and late-season, and nearly equal in early season compared with references sites.

\section{Nest Density}

Nest density was significantly lower on rehabilitation sites than on reference sites $(|t|=4.3, p=0.02$; Table 2). Also, fewer species used rehabilitation sites for nesting (Table 2). An increasing trend was observed for the number of nests on rehabiltation sites; semipalmated sandpipers were the only species observed nesting on rehabilitation sites in the first year of the study, but species diversity had increased to eight by the third year of this study (Table 2).

\section{DISCUSSION}

The intention of rehabilitating tundra impacted by development activities is to eventually return habitat characteristics to a state similar to that of pre-development. We found that our rehabilitation sites in northern Alaska that are under 10 years into what is presumed to be a multidecade process have densities of birds that are estimated to be comparable to reference sites, except for lower densities of shorebirds and passerines in mid and early seasons, respectively, and higher densities of passerines and shorebirds in the late season. However, timing of use, species composition, and behavior of birds vary from reference sites. Rehabilitation sites also tended to support significantly fewer nests.

Birds on rehabilitation sites were primarily observed foraging and resting, while behavior observed on reference sites was more diverse with courtship displays, lounging, feeding, nesting, and territorial aggression being commonly observed. The absence of any observed breeding 
TABLE 2. Comparison of nest density (SE) and number of nesting species at rehabilitation and paired reference sites in $2012-14$.

\begin{tabular}{|c|c|c|c|c|}
\hline & Treatment & $\#$ of discovered nests & Nests $/ \mathrm{km}^{2}(\mathrm{SE})$ & Nesting species (\# nests) \\
\hline \multirow[t]{2}{*}{2012} & Rehabilitation sites & 6 & $15.28(7.94)$ & Semipalmated Plover (6) \\
\hline & Tundra sites & 31 & $94.67(15.20)$ & $\begin{array}{l}\text { Dunlin (3), Greater White-fronted Goose (3), Lapland Longspur (3), } \\
\text { Long-billed Dowitcher (2), Pectoral Sandpiper (2), Red Phalarope (3), } \\
\text { Red-necked Phalarope (4), Semipalmated Sandpiper (9), Stilt Sandpiper (2) }\end{array}$ \\
\hline \multirow[t]{2}{*}{2013} & Rehabilitation sites & 7 & $18.77(9.61)$ & $\begin{array}{l}\text { American Golden-Plover (1), Greater White-fronted Goose (1), } \\
\text { Northern Pintail (1), Semipalmated Plover (4) }\end{array}$ \\
\hline & Tundra sites & 31 & $99.68(19.41)$ & $\begin{array}{l}\text { American Golden-Plover (1), Canada Goose (2), Dunlin (1), Greater } \\
\text { White-fronted Goose (3), Long-billed Dowitcher (2), Pectoral Sandpiper (2), } \\
\text { Red Phalarope (1), Red-necked Phalarope (3), Semipalmated Sandpiper (8), } \\
\text { Stilt Sandpiper (2) }\end{array}$ \\
\hline \multirow[t]{2}{*}{2014} & Rehabilitation sites & 12 & $41.54(12.88)$ & $\begin{array}{l}\text { Cackling Goose (2), Greater Scaup (1), King Eider (2), Lapland Longspur (1), } \\
\text { Savannah Sparrow (1), Semipalmated Plover (3), Semipalmated Sandpiper (1), } \\
\text { Short-eared Owl (1) }\end{array}$ \\
\hline & Tundra sites & 50 & $140.38(14.37)$ & $\begin{array}{l}\text { Greater White-fronted Goose (7), King Eider (1), Dunlin (1), } \\
\text { Lapland Longspur (5), Long-billed Dowitcher (3), Northern Pintail (1), } \\
\text { Pectoral Sandpiper (14), Semipalmated Sandpiper (9), Stilt Sandpiper (2), } \\
\text { Red Phalarope (4), Red-necked Phalarope (3) }\end{array}$ \\
\hline
\end{tabular}

behavior was attributed partly to the fewer birds nesting at rehabilitation sites. Differences in bird use as indicated by other behaviors were limited to foraging and resting and may be related to differences in the plant communities between rehabilitation and reference sites. Vegetation and water bodies that have developed at rehabilitation sites for 3-10 years appear to be most valuable to wildlife late in the season when bird density was significantly higher compared to reference sites. Rehabilitation sites are also used for resting, possibly because of the proximity to a food source as well as water bodies that provide escape habitat.

Rehabilitated abandoned test wells with associated sumps in northern Canada have been shown to have different plant communities than those in surrounding tundra, even after more than 30 years of recovery (Kearns et al., 2015). Similarly, the soil at an exploration well site undergoing rehabilitation on Alaska's coastal plain consisted primarily of gravel and sandy gravel eight years after rehabilitation (Kidd et al., 2004). Plant communities, water bodies, and amount of exposed gravel in this study were visually different between the rehabilitation sites and reference sites (R.L. Bentzen and J. Liebezeit, pers. observ.), and the birds nesting on rehabilitation sites were primarily those associated with bare, open habitats (e.g., Semipalmated Plovers, American Golden-Plovers). Differences in bird use indicate that rehabilitation sites provide only some of the functions found in the predisturbance state. More time is needed for rehabilitation sites to support a breeding bird community, but the process is underway as demonstrated by the increasing trend of nest density at rehabilitation sites.

Differences in the vegetation (J. Liebezeit, pers. observ.) of the rehabilitation sites may explain patterns observed in this study with variable densities of the three bird guilds across the season and in a different pattern at rehabilitation compared to reference sites. We found that densities of the three bird guilds varied across the season and the pattern differed for rehabilitation and reference sites. Both shorebird and passerine densities increased across the season at rehabilitation sites and decreased across the season at the reference sites. This temporal pattern of bird activity is likely explained by a combination of factors including habitat, plant community, and snow cover. The decrease in density at reference sites across the season is likely due to the behavior of breeding birds; after incubation starts, many male birds no longer display and, depending on mating strategy, may depart the area completely, as is expected. The pattern of increasing densities from early to late season at rehabilitation sites could be in part due to failed breeders moving away from the breeding habitat found at reference sites. The higher late-season densities of shorebirds and passerines at rehabilitation sites may indicate that some attributes are favorable to these two guilds such as potentially higher food availability, or preferential selection of species such as aquatic forbs that are typically uncommon in reference tundra but may occur widely at rehabilitation sites.

Surprisingly, detectability was always lower at the rehabilitation sites than at the reference sites even though rehabilitation sites had a more open habitat. The difference in detectability may be due to the reference sites having higher nest density; many breeding activities are fairly obvious, especially during the early season when birds are displaying, mate guarding, as well as the presence of more conspicuously plumaged breeding birds.

Nest density on rehabilitation sites doubled in the third year of the study, and the number of nesting species increased across years (Table 2). However, nest density and number of nesting species also went up across years on the reference sites. Because similar changes were seen at rehabilitation and reference sites it is not likely that increases seen in the third year reflected marked changes in habitat conditions on the rehabilitation sites, but simply the annual variability present in the Arctic.

In conclusion, both shorebird and passerine densities were significantly lower at rehabilitation sites than at reference sites during periods closely linked with nesting (early season for shorebirds and mid-season for passerines). 

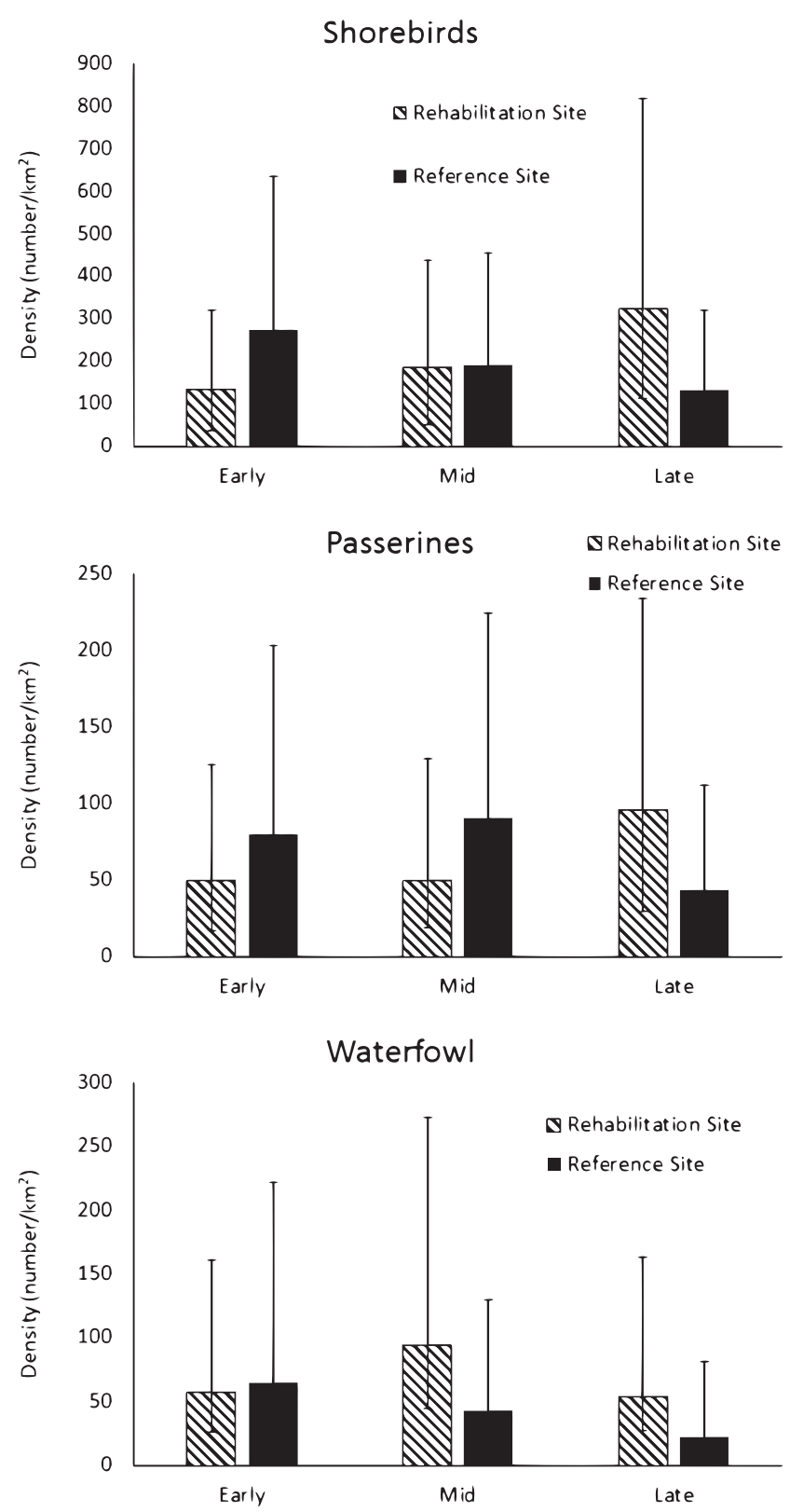

FIG. 4. Line-transect density estimates for each guild by treatment (rehabilitation versus reference sites) and each of the three sampling periods per season. Shown are estimates of density $(\hat{D})$ in number $/ \mathrm{km}^{2}$ with their $95 \%$ confidence intervals $(95 \% \mathrm{CI})$.

Shorebird and passerine densities were significantly higher at reference sites late-season, the period after nesting. Nest density and species composition were higher at reference sites. Bird use over three consecutive summers indicated that rehabilitation efforts (see online Appendix 1) create habitat that supports some aspects of bird life, primarily foraging and resting, and that birds are at least beginning to breed in these areas. Differences in habitat and hydrology are likely the primary factors affecting differences in bird use when comparing rehabilitation sites to reference sites. Especially notable is the higher densities of birds on rehabilitation sites in late summer, possibly due to high primary production in these areas in response to the fertilization which occurred as part of rehabilitation activities. Our study shows that rehabilitation sites do not yet provide bird habitat comparable to nearby reference sites and, by extension, do not provide habitat comparable to that found prior to development, but that birds are using these rehabilitated sites primarily as foraging and resting areas. Furthermore, our work sets an important baseline for continued monitoring, which will be required to understand the long-term trajectories of habitat suitability of rehabilitated sites for the region's birds.

\section{ACKNOWLEDGEMENTS}

This work was initiated at the request of BP Exploration (Alaska), Inc. We thank BP Exploration (Alaska), Inc., for their generous financial assistance, encouragement, and help with our field logistics. BP staff and contractors Christina Pohl, Tatyana Venegas, and Kyla Choquette were instrumental in the success of this project. We would also particularly like to recognize the dedication and hard work of fieldwork leaders Amanda Klehr, Zak Pohlen, Jie Kim, and Erica Escajeda. We also thank Andra Bontrager and J. Tyler DeJong for GIS assistance. This project would not have been possible without generous support from the National Fish and Wildlife Foundation.

\section{APPENDIX 1}

The following table is available in a supplementary file to the online version of this article at:

https://arcticjournalhosting.ucalgary.ca/arctic/index.php/ arctic/rt/suppFiles/4747/0

TABLE S1. Rehabilitation sites.

\section{REFERENCES}

Anderson, B.A., Johnson, C.B., Cooper, B.A., Smith, L.N., and Stickney, A.A. 1999. Habitat associations of nesting Spectacled Eiders on the Arctic Coastal Plain of Alaska. In: Goudie, R.I., Peterson, M.R., and Robertson, G.J., eds. Behavior and ecology of sea ducks. Canadian Wildlife Service Occasional Paper 100. Ottawa, Ontario: Environment Canada. 27-32.

Andres, B.A., Johnson, J.A., Brown, S.C., and Lanctot, R.B. 2012. Shorebirds breed in unusually high densities in the Teshekpuk Lake Special Area, Alaska. Arctic 65(4):411-420. https://doi.org/10.14430/arctic4239

Bart, J., Platte, R.M., Andres, B., Brown, S., Johnson, J.A., and Larned, W. 2013. Importance of the National Petroleum Reserve-Alaska for aquatic birds. Conservation Biology 27(6):1304-1312. https://doi.org/10.1111/cobi.12133

Bentzen, R.L. 2016. Tundra nesting birds. In: Bishop, S.C., and Streever, B., eds. Long-term ecological monitoring in BP's North Slope oil fields through 2014. Anchorage: BP Exploration (Alaska) Inc. 23-32. 
Buckland, S.T., Anderson, D.R., Burnham, K.P., Laake, J.L., Borchers, D.L., and Thomas, L. 2001. Introduction to distance sampling: Estimating abundance of biological populations. Oxford: Oxford University Press.

Cardoso da Silva, J.M., and Vickery, P.D. 2002. Birds. In: Perrow, M.R., and Davy, A.J., eds. Handbook of ecological restoration. New York: Cambridge University Press. 376-388. https://doi.org/10.1017/CBO9780511549984.021

DeVault, T.L., Scott, P.E., Bajema, R.A., and Lima, S.L. 2002. Breeding bird communities of reclaimed coal-mine grasslands in the American Midwest. Journal of Field Ornithology 73(3):268-275.

Dieni, J.S., and Jones, S.L. 2002. A field test of the area search method for measuring breeding bird populations. Journal of Field Ornithology 73(3):253-257.

Duncan, S. 2011. Habitat associations of grassland and shrubland bird communities at reclaimed surface-mines in southern Illinois. MS thesis, Southern Illinois University, Illinois.

Galligan, E.W., DeVault, T.L., and Lima, S.L. 2006. Nesting success of grassland and savanna birds on reclaimed surface coal mines of the midwestern United States. The Wilson Journal of Ornithology 118(4):537-546. https://doi.org/10.1676/05-086.1

Johnson, S.R., and Herter, D.R. 1989. The birds of the Beaufort Sea. Anchorage: British Petroleum Exploration (Alaska).

Johnson, J.A., Lanctot, R.B., Andres, B.A., Bart, J.R., Brown, S.C., Kendall, S.J., and Payer, D.C. 2007. Distribution of breeding shorebirds on the Arctic Coastal Plain of Alaska. Arctic 60(3):277-293.

https://doi.org/10.14430/arctic220

Jorgenson, M.T., and Joyce, M.R. 1994. Six strategies for rehabilitating land disturbed by oil development in Arctic Alaska. Arctic 47(4):374-390. https://doi.org/10.14430/arctic1311

Kearns, N.B., Jean, M., Tissier, E.J., and Johnstone, J.F. 2015. Recovery of tundra vegetation three decades after hydrocarbon drilling with and without seeding of non-native grasses. Arctic 68(1):16-31. https://doi.org/10.14430/arctic4445

Kidd, J.G., Streever, B., Joyce, M.R., and Fanter, L.H. 2004. Wetland restoration of an exploratory well on Alaska's North Slope: A learning experience. Ecological Restoration 22:30-38.

Kidd, J.G., Streever, B., and Jorgenson, M.T. 2006. Site characteristics and plant community development following partial gravel removal in an Arctic oilfield. Arctic, Antarctic, and Alpine Research 38(3):384-393.
Liebezeit, J.R., Kendall, S.J., Brown, S., Johnson, C.B., Martin, P., McDonald, T.L., Payer, D.C., et al. 2009. Influence of human development and predators on nest survival of tundra birds, Arctic Coastal Plain, Alaska. Ecological Applications 19(6): $1628-1644$.

https://doi.org/10.1890/08-1661.1

Marques, F.F.C., and Buckland, S.T. 2003. Incorporating covariates into standard line transect analyses. Biometrics 59(4):924-935. https://doi.org/10.1111/j.0006-341X.2003.00107.x

National Research Council. 2003. Cumulative environmental effects of oil and gas activities on Alaska's North Slope. Washington D.C.: National Academies Press. https://doi.org/10.17226/10639

Ormerod, S.J. 2003. Restoration in applied ecology: Editor's introduction. Journal of Applied Ecology 40(1):44-50. https://doi.org/10.1046/j.1365-2664.2003.00799.x

Raynolds, M.K., Walker, D.A., Ambrosius, K.J., Brown, J., Everett, K.R., Kanevskiy, M., Kofinas, G.P., Romanovsky, V.E., Shur, Y., and Webber, P.J. 2014. Cumulative geoecological effects of 62 years of infrastructure and climate change in ice-rich permafrost landscapes, Prudhoe Bay Oilfield, Alaska. Global Change Biology 20(4):1211 - 1224. https://doi.org/10.1111/gcb.12500

Ruiz-Jaen, M.C., and Aide, T.M. 2005. Restoration success: How is it being measured? Restoration Ecology 13(3):569-577. https://doi.org/10.1111/j.1526-100X.2005.00072.x

Š́lek, M. 2012. Spontaneous succession on opencast mining sites: Implications for bird biodiversity. Journal of Applied Ecology 49(6):1417-1425. https://doi.org/10.1111/j.1365-2664.2012.02215.x

Scott, P.E., and Lima, S.L. 2004. Exotic grasslands on reclaimed midwestern coal mines: An ornithological perspective. Weed Technology 18:1518-1521.

Streever, W.J., McKendrick, J.D., Fanter, L., Anderson, S.C., Kidd, J., and Portier, K.M. 2003. Evaluation of percent cover requirements for revegetation of disturbed sites on Alaska's North Slope. Arctic 56(3):234-248.

https://doi.org/10.14430/arctic619

Thomas, L., Buckland, S.T., Rexstad, E.A., Laake, J.L., Strindberg, S., Hedley, S.L., Bishop, J.R.B., Marques, T.A., and Burnham, K.P. 2010. Distance software: Design and analysis of distance sampling surveys for estimating population size. Journal of Applied Ecology 47(1):5 - 14 . https://doi.org/10.1111/j.1365-2664.2009.01737.x

U.S. Energy Information Administration. 2015. Top 100 U.S. oil and gas fields, March 2015. Washington, D.C.: U.S. Department of Energy.

https://www.eia.gov/naturalgas/crudeoilreserves/top100/pdf/ top100.pdf 